University of Nebraska - Lincoln

DigitalCommons@University of Nebraska - Lincoln

Publications, Agencies and Staff of the U.S.

Department of Commerce

U.S. Department of Commerce

2009

\title{
Transformation of the offshore benthic community in Lake Michigan: recent shift from the native amphipod Diporeia spp. to the invasive mussel Dreissena rostriformis bugensis
}

\author{
Thomas F. Nalepa \\ NOAA, thomas.nalepa@noaa.gov \\ David L. Fanslow \\ Great Lakes Environmental Research Laboratory \\ Gregory A. Lang \\ Great Lakes Environmental Research Laboratory
}

Follow this and additional works at: https://digitalcommons.unl.edu/usdeptcommercepub

Part of the Environmental Sciences Commons

Nalepa, Thomas F.; Fanslow, David L.; and Lang, Gregory A., "Transformation of the offshore benthic community in Lake Michigan: recent shift from the native amphipod Diporeia spp. to the invasive mussel Dreissena rostriformis bugensis" (2009). Publications, Agencies and Staff of the U.S. Department of Commerce. 377.

https://digitalcommons.unl.edu/usdeptcommercepub/377

This Article is brought to you for free and open access by the U.S. Department of Commerce at DigitalCommons@University of Nebraska - Lincoln. It has been accepted for inclusion in Publications, Agencies and Staff of the U.S. Department of Commerce by an authorized administrator of DigitalCommons@University of Nebraska - Lincoln. 


\title{
Transformation of the offshore benthic community in Lake Michigan: recent shift from the native amphipod Diporeia spp. to the invasive mussel Dreissena rostriformis bugensis
}

\author{
THOMAS F. NALEPA, DAVID L. FANSLOW AND GREGORY A. LANG \\ Great Lakes Environmental Research Laboratory, 2205 Commonwealth Blvd., Ann Arbor, MI, U.S.A.
}

\section{SUMMARY}

1. The native amphipod Diporeia spp. was once the dominant benthic organism in Lake Michigan and served as an important pathway of energy flow from lower to upper trophic levels. Lake-wide surveys were conducted in 1994/1995, 2000 and 2005, and abundances of Diporeia and the invasive bivalves Dreissena polymorpha (zebra mussel) and Dreissena rostriformis bugensis (quagga mussel) were assessed. In addition, more frequent surveys were conducted in the southern region of the lake between 1980 and 2007 to augment trend interpretation.

2. Between 1994/1995 and 2005, lake-wide density of Diporeia declined from 5365 to $329 \mathrm{~m}^{-2}$, and biomass (dry weight, DW) declined from 3.9 to $0.4 \mathrm{~g} \mathrm{DW} \mathrm{m}^{-2}$. The percentage of all sites with no Diporeia increased over time: 1.1\% in 1994/1995, 21.7\% in 2000 and $66.9 \%$ in 2005. On the other hand, total dreissenid density increased from 173 to $8816 \mathrm{~m}^{-2}$, and total biomass increased from 0.4 to $28.6 \mathrm{~g} \mathrm{DW} \mathrm{m}^{-2}$. Over this 10-year time period, D. r. bugensis displaced D. polymorpha as the dominant dreissenid, comprising $97.7 \%$ of the total population in 2005. In 2007, Diporeia was rarely found at depths shallower than $90 \mathrm{~m}$ and continued to decline at greater depths, whereas densities of D. r. bugensis continued to increase at depths greater than $50 \mathrm{~m}$.

3. The decline in Diporeia occurred progressively from shallow to deep regions, and was temporally coincident with the expansion of $D$. polymorpha in nearshore waters followed by the expansion of D. r. bugensis in offshore waters. In addition, Diporeia density was negatively related to dreissenid density within and across depth intervals; the latter result indicated that dreissenids in shallow waters remotely influenced Diporeia in deep waters.

4. With the loss of Diporeia and increase in D. r. bugensis, the benthic community has become a major energy sink rather that a pathway to upper trophic levels. With this replacement of dominant taxa, we estimate that the relative benthic energy pool increased from 17 to $109 \mathrm{kcal} \mathrm{m}^{-2}$ between 1994/1995 and 2005, and to $342 \mathrm{kcal} \mathrm{m}^{-2}$ by 2007. We project that previously observed impacts on fish populations will continue and become more pronounced as the D. r. bugensis population continues to expand in deeper waters.

Keywords: benthos, food webs, invasive species, lakes, populations

Correspondence: Thomas F. Nalepa, Great Lakes Environmental Research Laboratory, 2205 Commonwealth Blvd., Ann Arbor, MI 48103, U.S.A. E-mail: thomas.nalepa@noaa.gov 


\section{Introduction}

Invasive species can cause changes in host aquatic ecosystems at many levels of organization, with perhaps the most common change being the loss of native species and a decline in biodiversity (Moyle \& Light, 1996; Simon \& Townsend, 2003; J.L. Molnar, R.L. Gamboa, C. Revenga and M.D. Spalding, unpublished data). Invaders negatively impact native species through competition, predation and habitat alteration (Richter et al., 1997). Frequently, invasive species have a phase of rapid population growth and range expansion, and native species can be lost over a short time span (Diamond \& Case, 1986; Crooks \& Soule, 1999). Such rapid shifts in community dominance have complex implications for ecosystem function. Ultimately, functional impacts depend on food web roles and biological attributes of the species involved, and also on the particular habitat. In theory, if the invader plays a very similar functional role to the native species it has displaced, then ecosystem disruption would be minimal (Dick \& Platvoet, 2000; Palmer \& Ricciardi, 2005). More often though, because native species are well adapted to local conditions and evolved into an ecological niche over time, displacement will have at least some functional consequences. The displacement of species will be most disruptive where severe environmental conditions preclude the presence of a wide variety of species (Lodge, 1993; Covich, Palmer \& Crowl, 1999). Moreover, functional changes are particularly pronounced in large homogeneous environments where strong physicochemical gradients do not exist (Moyle \& Light, 1996). Such severe conditions, minimal diversity and lack of strong spatial gradients describes the benthic habitat in the offshore region of the Great Lakes.

In this study, we document a lake-wide replacement of a native species by an invader in Lake Michigan, and present evidence that the ensuing change in the composition of the benthic community will have a large functional impact. The taxa involved in this recent, dramatic transition are the native amphipod Diporeia spp., which has virtually disappeared, and the invasive mussel Dreissena rostriformis bugensis (Andrusov), which has become dominant. Diporeia are part of a fauna that inhabit cold, deep proglaciated lakes, brackish estuaries and coastal margins in the Holarctic region (Bousfield, 1989). Prior to the introduction and spread of two dreissenid species,
Dreissena polymorpha (Pallas) and D. r. bugensis, Diporeia was the dominant benthic organism in deeper waters ( $>30 \mathrm{~m}$ ) of all the Great Lakes, comprising over $70 \%$ of benthic biomass in this offshore region (Cook \& Johnson, 1974; Nalepa, 1989). It was present but less dominant in open, shallow regions $(<30 \mathrm{~m})$, and naturally absent from shallow, warm bays and basins. As a benthic detritivore, Diporeia feeds on organic material settled from the water column, being particularly reliant on material deposited during the spring diatom bloom (Gardner et al., 1990). Depending on depth and seasonal period, epilithic algae and detritus/bacteria are also a source of food (Guiguer \& Barton, 2002; Sierszen, Peterson \& Scharold, 2006). In general though, ingestion rates, growth rates and lipid levels are at a seasonal peak during or just after the spring bloom (Gardner et al., 1985, 1989; Dermott \& Corning, 1988). Diporeia are fed upon by many fish species (Scott \& Crossman, 1973; Wells, 1980), thereby serving as a keystone organism in the cycling of energy between lower and upper trophic levels. Diporeia populations began declining soon after D. polymorpha and D. r. bugensis became established in the Great Lakes in the late 1980s, and large areas in all the Great Lakes except Lake Superior are now completely devoid of this organism (Dermott \& Kerec, 1997; Nalepa et al., 2006a, 2007; Watkins et al., 2007). Exact reasons for the negative response of Diporeia to dreissenids are not clear, and may be related to a combination of factors (Nalepa et al., 2006a; Nalepa, Rockwell \& Schloesser, 2006b).

In Lake Michigan, declines in Diporeia were first observed in the southern portion of the lake in the early 1990s, a few years after D. polymorpha first colonized that region in 1989 (Nalepa et al., 1998). As D. polymorpha continued to spread, declines in Diporeia became more extensive, and by 2000 Diporeia were gone or rare in the far southern and northern portions of the lake, and along the eastern shoreline to depths of $50 \mathrm{~m}$ (Nalepa et al., 2006a). The other dreissenid, D. r. bugensis, became established in the lake in 1997 (Nalepa et al., 2001). This species was found in Lake Ontario 7 years prior to being found in Lake Michigan, and studies documented several important aspects of its expansion. First, unlike D. polymorpha, D. r. bugensis attained relatively high densities in deeper regions $(>50 \mathrm{~m}$ ) and, second, it displaced D. polymorpha in shallow regions (Mills et al., 1999). We hypothesized that a similar expansion 
pattern into offshore regions would occur in Lake Michigan, and that such an expansion would have strong, additional consequences to remaining Diporeia populations.

We here document lake-wide trends in Diporeia, D. r. bugensis and D. polymorpha in Lake Michigan over the period between 1994/1995 and 2005, and also provide more detailed trends in the southern basin of the lake between the early/mid-1980s (before dreissenid invasions) and 2007. While previous studies in Lake Michigan and the other Great Lakes have documented declines in Diporeia relative to dreissenids, changes in biomass and energy costs of such a shift in community composition have not been estimated. We show that the Diporeia population has declined to levels that make it no longer relevant as a pathway for energy cycling in the Lake Michigan food web, and also show that D. r. bugensis has expanded, displaced $D$. polymorpha, and now serves as a major energy sink within the lake.

\section{Methods}

Population trends of Diporeia and dreissenids in Lake Michigan were derived from lake-wide surveys in 1994/1995, 2000 and 2005. Numbers of sites sampled were 87, 157 and 160 in each of the three periods respectively. Each year, samples were collected in the late summer-early autumn period (August-September). Location of all sampling sites and collection dates are given in Nalepa et al. (2008). Of the sites sampled lake wide in 2000 and 2005, a subset of 40 sites in the southern basin was sampled again in 2006 and 2007. These sites were part of a long-term monitoring programme and also sampled in 198081, 1986-87, 1992-93 and every year between 1998 and 2007. Samples at these 40 sites were collected in spring, summer and autumn each year prior to 2000, and also in 2004 and 2005. Otherwise, samples were collected in late summer/autumn. Samples at each site were consistently taken in triplicate with a Ponar grab (sampling area $=0.046 \mathrm{~m}^{2}$ ). Sediments were washed through an elutriation device fitted with a $0.5-\mathrm{mm}$ mesh net, and retained residue preserved in 5\% formalin containing rose bengal stain. In the laboratory, all Diporeia and dreissenids were picked and counted under a low-power magnifier lamp (1.5×). In replicate samples with high numbers of either taxa, individuals were sub-sampled by using a folsom plankton splitter (Diporeia), or by selecting a random quadrat of individuals that were evenly distributed in a gridded tray (dreissenids).

Dry-weight biomass of Diporeia in 1994/1995 was reported in Nalepa et al. (2000). In this previous study, biomass was derived from measured length-weight relationships and size-frequencies over various depth intervals and lake regions. To calculate biomass in 2005, mean weight in 1994-95 within each of four depth intervals ( $\leq 30,31-50,51-90$ and $>90 \mathrm{~m}$ ) was multiplied by mean density in that interval in 2005 . We assumed that average weight (i.e. biomass divided by density) did not change over the 10-year time period since length-weight relationships and most size frequencies remained stable as densities declined between 1997 and 2002 (Nalepa et al., 2006a). Lakewide biomass in 1994/1995 was previously reported as the mean of all collected sites (Nalepa et al., 2000). Since greater numbers of sites were sampled in 2005, we calculated 2005 lake-wide biomass and re-calculated 1994/1995 lake-wide biomass by first multiplying mean biomass in each of the four intervals by lake area within that interval, summing the value for all intervals, and then dividing by total lake area. Thus, biomasses were pro-rated as a function of lake area within a given depth interval. The proportion of lake area in the $\leq 30,31-50,51-90$ and $>90 \mathrm{~m}$ intervals was $12.7 \%, 14.7 \%, 31.0 \%$ and $41.5 \%$ respectively. Biomass was not determined for 2000 .

Dry-weight biomass of dreissenids in 1994/1995 and 2005 was also estimated from size frequencies and derived length-weight relationships. All dreissenids collected in 1994/1995 were measured (shell length), whereas in 2005 dreissenids were measured at 34 representative sites. The sites chosen in 2005 were considered representative of the lake as a whole; that is, they were located mostly along depth transects on the east and west side of the lake, and in three lake regions (south, central and north; Nalepa et al., 2000). Of the 34 sites, 12 were located in the $\leq 30 \mathrm{~m}$ interval, 10 in the $31-50 \mathrm{~m}$ interval and 12 in the $51-90 \mathrm{~m}$ interval. Shell lengths were binned into $1 \mathrm{~mm}$ categories from 1 to $31 \mathrm{~mm}$.

Length-weight relationships for both D. polymorpha and $D$. $r$. bugensis were derived from specimens collected at two sites ( 25 and $45 \mathrm{~m}$ ) on the east side of the lake (off Muskegon, Michigan), and at two sites (18 and $45 \mathrm{~m}$ ) on the west side of the lake (off Waukegan, Illinois) in 2004. These sites represented 
conditions above and below the thermocline, which is about $30 \mathrm{~m}$ in Lake Michigan. Samples were collected on seven dates at the east sites (20 April, 3 June, 23 June, 21 July, 31 August, 21 September and 27 October) and on four dates at the west sites (27 May, 1 July, 25 August and 20 September). Mussels were collected with a Ponar grab, kept cool and shellfree dry weights (DW) determined within $48 \mathrm{~h}$. For each species, shell lengths of 25 individuals collected on each date were measured (range 9-30 mm), soft tissues placed into pre-weighed aluminum planchets, dried at $60{ }^{\circ} \mathrm{C}$ for $48 \mathrm{~h}$, and then re-weighed. A length-weight relationship derived from the 18 and $25 \mathrm{~m}$ sites (all dates) was used to determine biomass at all sites $\leq 30 \mathrm{~m}$ where mussels were measured $(n=12)$. Similarly, a length-weight relationship derived from the two $45 \mathrm{~m}$ sites on all dates was used to determine biomass at sites $>30 \mathrm{~m}$ where mussels were measured $(n=22)$. The average weight of a mussel in these two intervals was determined and then used to calculate interval-specific biomass at all other sites (i.e. average weight $\times$ density). Lake-wide biomass for dreissenids was determined as previously described for Diporeia.

While data from all sites were included in plots of density distributions, only sites in the main basin were included in statistical analysis and calculation of lake-wide biomass. Sites located in two bays, Green Bay and Grand Traverse Bay, were excluded since a greater number of sites were sampled in these two bays in 2000 and 2005 compared to 1994/1995 (29 versus 6). Thus, numbers of sites used in the actual analysis were 82, 128 and 131 in 1994/1995, 2000 and 2005 respectively. The sites were placed into four depth intervals ( $\leq 30,31-50,51-90$ and $>90 \mathrm{~m}$ ), and density differences between years and year $\times$ interval interactions were tested with a two-way ANOVA after ln +1 transformation to homogenize variances. Station means were treated as the source of variation within intervals. When differences between years were significant $(P<0.05)$, Tukey's post hoc multiple range test was used to make pair-wise comparisons. Since some sites $(n=34)$ were sampled in all three periods, we also examined differences using repeated measures ANOVA (Green, 1993). Statistical outcomes were similar to those of the two-way ANOVA; thus, only outcomes of the two-way ANOVA are reported. Since all 40 sites sampled in the southern region in 2005 were re-sampled in 2006 and 2007, differences between the 3 years were tested with repeated measures ANOVA after $\ln +1$ transformation.

\section{Results}

Over the 10-year period between 1994/1995 and 2005, mean lake-wide density of Diporeia declined from 5365 to $329 \mathrm{~m}^{-2}$, and biomass declined from 3.9 to $0.4 \mathrm{~g} \mathrm{DW} \mathrm{m}^{-2}$. Densities were significantly different between the three sampling periods $\left(F_{[2,329]}=98.13\right.$, $P<0.001)$, with densities significantly lower in 2000 compared to $1994 / 1995(P<0.001)$, and significantly lower in 2005 compared to $2000(P<0.001)$ (Table 1$)$. The year $\times$ interval interaction was also significant $\left(F_{[6,329]}=4.67, P<0.001\right)$, indicating declines were not consistent across all depth intervals. Over the 10year period, declines were $96.9 \%, 99.6 \%, 91.6 \%$ and $72.8 \%$ in the $\leq 30,31-50,51-90$ and $>90 \mathrm{~m}$ depth intervals, respectively. The percentage of all sites with no Diporeia increased over time: $1.1 \%$ in 1994/1995, $21.7 \%$ in 2000 and $66.9 \%$ in 2005 (Fig. 1).

Densities continued to decline at the southern basin sites between 2005 and 2007 (Fig. 2). Differences between 2005, 2006 and 2007 were significant $\left(F_{[2,}\right.$ $78]=10.17, \quad P \leq 0.001)$, with densities significantly lower in 2006 than in $2005(P<0.05)$ and densities

Table 1 Mean $\left( \pm\right.$ SE) density (no. $\mathrm{m}^{-2}$ ) of Diporeia spp., Dreissena polymorpha and Dreissena r. bugensis in Lake Michigan at each of four depth intervals in 1994/1995, 2000 and 2005

\begin{tabular}{lccc}
\hline \multicolumn{4}{c}{ Year } \\
\cline { 2 - 4 } & $1994 / 1995$ & 2000 & 2005 \\
\hline Diporeia $(\mathrm{m})$ & & & \\
$\leq 30$ & $3489 \pm 995$ & $870 \pm 324$ & $111 \pm 95$ \\
$31-50$ & $5850 \pm 1283$ & $2001 \pm 534$ & $23 \pm 15$ \\
$51-90$ & $6557 \pm 570$ & $3422 \pm 460$ & $548 \pm 131$ \\
$>90$ & $4567 \pm 414$ & $2752 \pm 448$ & $1244 \pm 217$ \\
D. polymorpha $(\mathrm{m})$ & & \\
$\leq 30$ & $702 \pm 512$ & $1836 \pm 467$ & $223 \pm 84$ \\
$31-50$ & $259 \pm 218$ & $1366 \pm 584$ & $446 \pm 106$ \\
$51-90$ & $<1 \pm<1$ & $18 \pm 8$ & $38 \pm 29$ \\
$>90$ & $0 \pm 0$ & $0 \pm 0$ & $<1 \pm<1$ \\
D. bugensis $(\mathrm{m})$ & & & \\
$\leq 30$ & $0 \pm 0$ & $37 \pm 23$ & $6285 \pm 1450$ \\
$31-50$ & $0 \pm 0$ & $25 \pm 17$ & $16415 \pm 2690$ \\
$51-90$ & $0 \pm 0$ & $0 \pm 0$ & $6472 \pm 1704$ \\
$>90$ & $0 \pm 0$ & $0 \pm 0$ & $12 \pm 7$ \\
\hline
\end{tabular}

The number of sites sampled each year in the $\leq 30,31-50,51-90$ and $>90 \mathrm{~m}$ intervals were respectively: 1994/1995 = 16, 12, 31, $23 ; 2000=36,38,41,13 ; 2005=38,39,41,13$. 

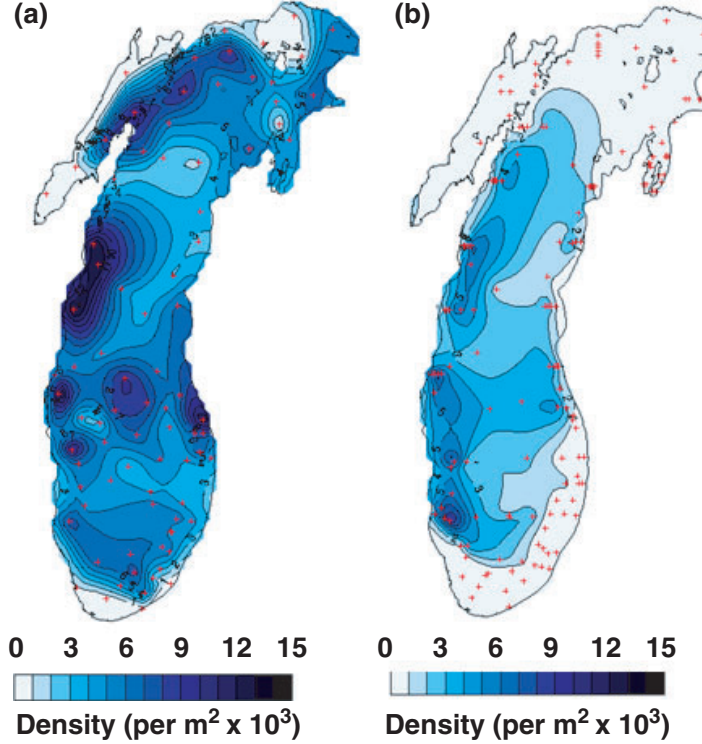

(b)

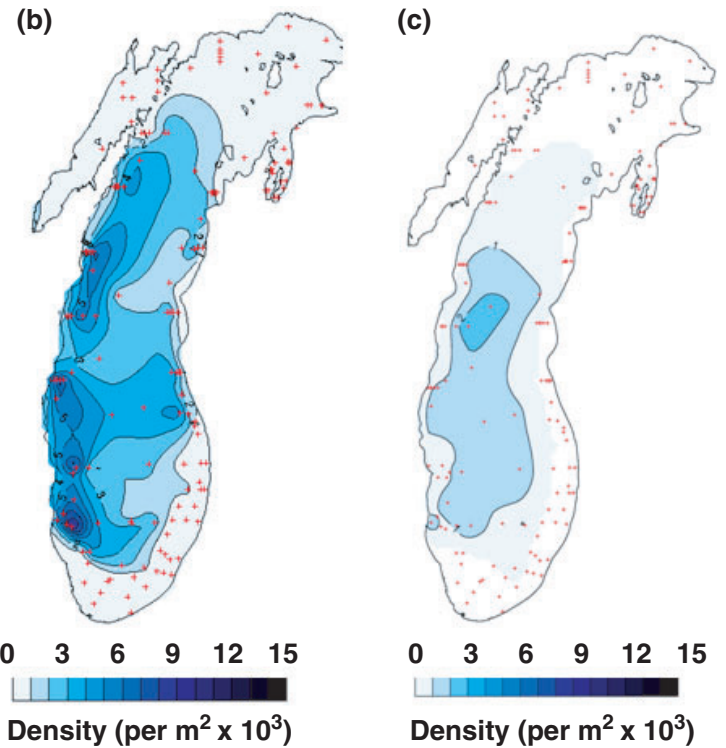

Density $\left(\right.$ per $\left.\mathrm{m}^{2} \times 10^{3}\right)$
Fig. 1 Mean density (no. $\mathrm{m}^{-2}$ ) of Diporeia in Lake Michigan. Small crosses denote sampling sites. (a) 1994-95, (b) 2000, (c) 2005.
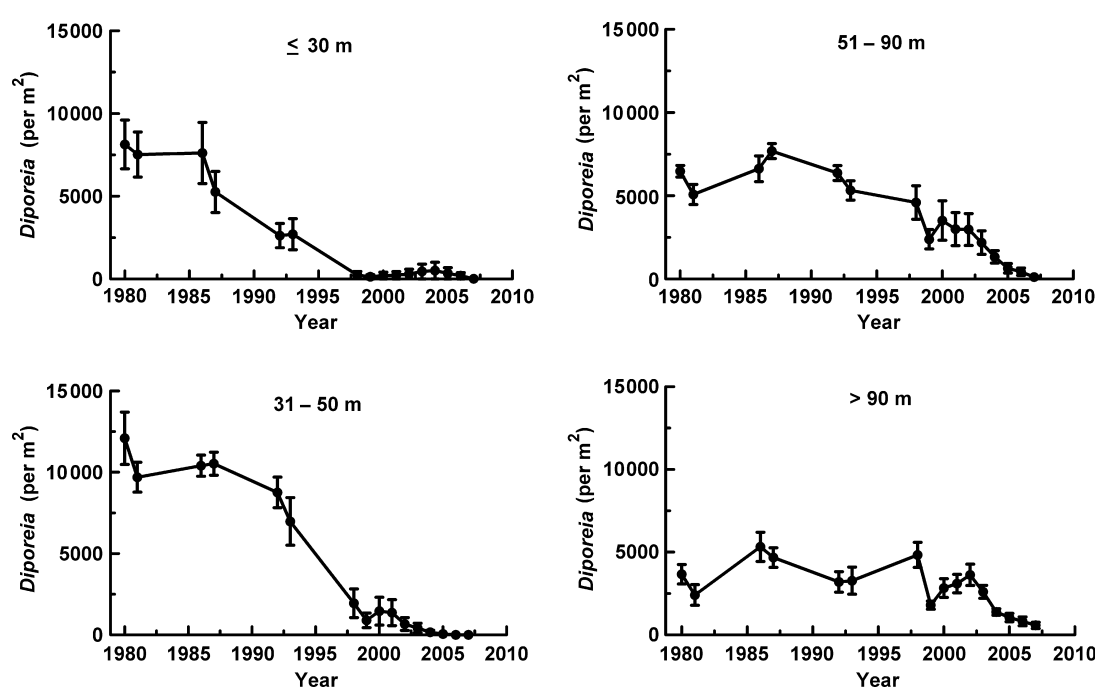

Fig. 2 Mean $\left( \pm\right.$ SE) density $\left(\right.$ no. $\left.\mathrm{m}^{-2}\right)$ of Diporeia in each of four depth intervals at 40 sites in the southern basin of Lake Michigan between 1980 and 2007. The number of sites in each depth interval was $\leq 30 \mathrm{~m}=12,31-50 \mathrm{~m}=10,51-90 \mathrm{~m}=12$, $>90 \mathrm{~m}=6$.

in 2007 significantly lower than $2006(P<0.01$; repeated measures ANOVA, post hoc). In the 1980s, prior to the Diporeia decline and the establishment of Dreissena (i.e. 1980-81, 1986-87), mean densities in the southern basin at the four depth intervals were 7162, 10687,6426 and $3925 \mathrm{~m}^{-2}$ respectively. In 2007, densities in the same intervals were 13, 1, 112 and $576 \mathrm{~m}^{-2}$. Based on these frequently sampled sites, it was evident that declines occurred progressively from shallow to deep regions. Initial declines occurred in the early/mid-1990s at the $\leq 30$ and 31-50 m intervals, in the late 1990s/early 2000s at the 51-90 m interval, and in 2004 at the $>90 \mathrm{~m}$ interval (Fig. 2).
While the lake-wide population of Diporeia declined between 1994/1995 and 2005, the total dreissenid population increased (Table 1). Mean total density of dreissenids increased from $173 \mathrm{~m}^{-2}$ in 1994/1995 to $8816 \mathrm{~m}^{-2}$ in 2005 , and total biomass increased from 0.4 to $28.6 \mathrm{~g} \mathrm{DW} \mathrm{m}^{-2}$. Densities were significantly different between the 3 years $\left(F_{[2,329]}=97.22, P<0.001\right)$, with densities significantly higher in 2000 compared to $1994 / 1995$ ( $P<0.001)$, and significantly higher in 2005 compared to $2000(P<0.001)$. The year $\times$ depth interval interaction was also significant $\left(F_{[6}\right.$, 329] $=9.87, P<0.001$ ), likely reflecting the expansion of dreissenids from shallow to deep water 
Fig. 3 Mean density (no. $\mathrm{m}^{-2}$ ) of Dreissena r. bugensis in Lake Michigan. Small crosses denote sampling sites. (a) 1994-95, (b) 2000, (c) 2005. For 2005, contours were manipulated slightly in the northern, midlake region to reflect more realistic patterns. Although not thoroughly sampled, this region would have few mussels because of extreme depths.

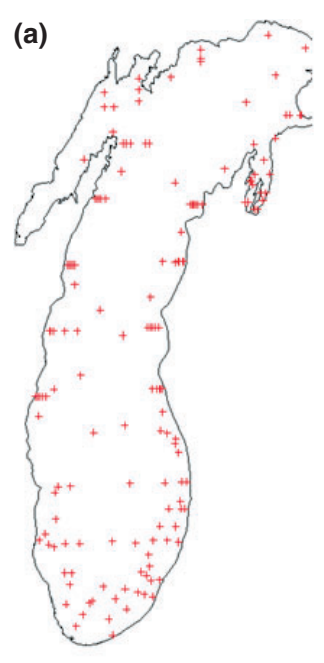

over this period (Table 1). Over the 10-year period, D. r. bugensis became established in the lake and displaced $D$. polymorpha as the dominant species. Dreissena $r$. bugensis was not found at any of the sites in 1994/1995, comprised only $1.9 \%$ of the total dreissenid population in 2000, but comprised $97.7 \%$ of the total in 2005 (Table 1). After becoming established in the northern portion of the lake in 1997 (Nalepa et al., 2001), it spread rapidly southward (Fig. 3). Overall densities were significantly greater in 2005 compared to 2000, and the difference was a function of depth $(P<0.01$, Tukey's post hoc test; year $\times$ interval interaction: $P<0.01)$. Mean densities increased from less than $50 \mathrm{~m}^{-2}$ in 2000 to more than $5000 \mathrm{~m}^{-2}$ in 2005 at each of the three shallowest depth
Density (no. per $\mathrm{m}^{2}$ )

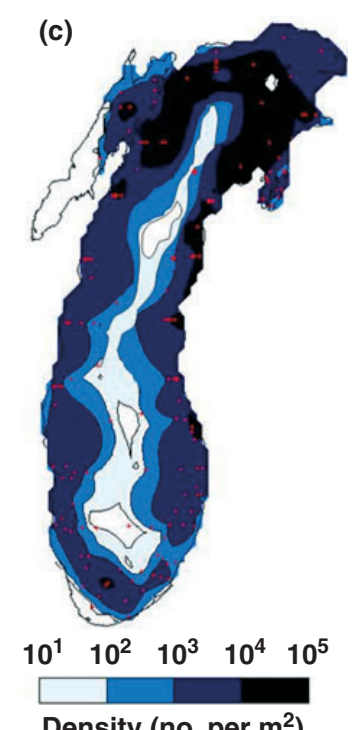

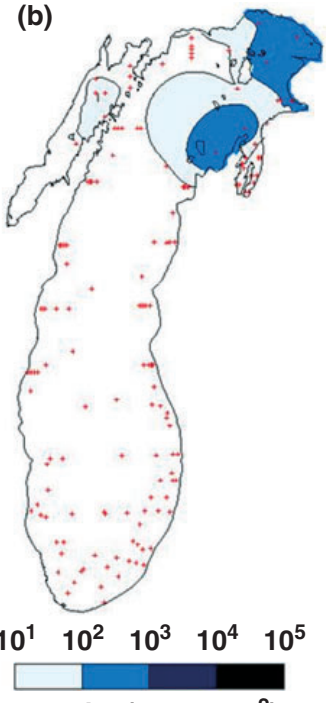

Density (no. per $\mathrm{m}^{2}$ ) intervals, but the increase at the $>90 \mathrm{~m}$ interval was minimal (Table 1). All individuals collected in both 2000 and 2005 were the profunda or deepwater phenotype (see Dermott \& Munawar, 1993).

In the southern basin, $D$. $r$. bugensis began to increase at the $<30$ and $31-50 \mathrm{~m}$ intervals in 2002, and began to increase at sites in the 51-90 m interval in 2005 (Fig. 4). As of 2007, densities appeared to have stabilized at the two former intervals, were still increasing at the latter, and were beginning to increase at the $>90 \mathrm{~m}$ interval. Mean maximum density in 2007 was $13289 \mathrm{~m}^{-2}$ in the $31-50 \mathrm{~m}$ interval.

Over the 10-year sampling period, densities of $D$. polymorpha increased between 1994/1995 and 2000, but then decreased between 2000 and 2005 (Table 1).
Fig. 4 Mean $( \pm S E)$ density $\left(\right.$ no. $\left.\mathrm{m}^{-2}\right)$ of Dreissena in each of four depth intervals at 40 sites in the southern basin of Lake Michigan between 1992 and 2007. The number of sites in each depth interval was $\leq 30 \mathrm{~m}=12,31-50 \mathrm{~m}=10,51-90 \mathrm{~m}=12$, $>90 \mathrm{~m}=6$. Solid circle, Dreissena polymorpha; open circle, Dreissena r. bugensis.
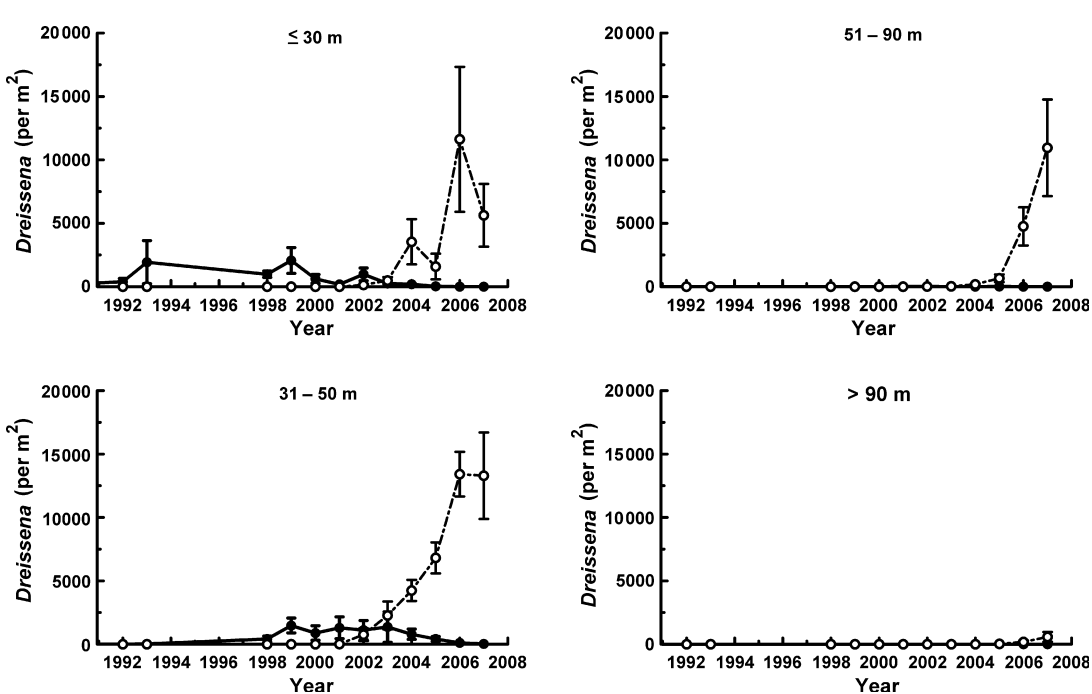

(C) 2008 Blackwell Publishing Ltd. No claim to original US government works, Freshwater Biology, 54, 466-479 
472 T. F. Nalepa et al.

Differences between these three periods were significant $(P<0.01$, Tukey's post hoc test; year $\times$ interval interaction: $P<0.01$ ). Although $D$. polymorpha was present, densities were minimal in the 51-90 and $>90 \mathrm{~m}$ intervals over the entire 10-year sampling period. In the southern basin, abundances of D. polymorpha continued to decline through 2007 (Fig. 4). As an example, mean maximum density in 2005 was $416 \mathrm{~m}^{-2}$ in the $31-50 \mathrm{~m}$ interval, but only $24 \mathrm{~m}^{-2}$ in the same interval in 2007.

As noted, the decline of Diporeia in the southern basin occurred progressively over time, occurring first at sites within the shallow intervals followed by declines at sites in the deeper intervals. This trend coincided with the increase in $D$. polymorpha to depths of $50 \mathrm{~m}$ through the 1990s, and then with increases in D. r. bugensis at deeper depths thereafter (Fig. 4). We used correlation analysis to determine if there was a negative relationship between densities of Diporeia and dreissenids within and across depth intervals over the time period between 1992 and 2007 (Table 2). Except for the $\leq 30 \mathrm{~m}$ interval, there was a strong negative relationship between the two taxa within each depth interval. In addition, there was a similarly strong negative relationship across intervals; that is, Diporeia densities at deep intervals were negatively correlated to dreissenid densities at shallower intervals.

\section{Discussion}

The offshore benthic community of Lake Michigan has undergone a major transformation over the past

Table 2 Correlation (Pearson's coefficients) between Diporeia and Dreissena spp. within and across depth intervals for the period between 1992 and 2007 in the southern basin of Lake Michigan

\begin{tabular}{lllll}
\hline & \multicolumn{4}{l}{ Dreissena spp. } \\
\cline { 2 - 5 } Diporeia & $\leq 30 \mathrm{~m}$ & $31-50 \mathrm{~m}$ & $51-90 \mathrm{~m}$ & $>90 \mathrm{~m}$ \\
\hline$\leq 30 \mathrm{~m}$ & -0.361 & & & \\
$31-50 \mathrm{~m}$ & $-0.758^{*}$ & $-0.823^{* *}$ & & \\
$51-90 \mathrm{~m}$ & $-0.704^{*}$ & $-0.773^{*}$ & $-0.962^{* *}$ & \\
$>90 \mathrm{~m}$ & $-0.753^{*}$ & $-0.678^{*}$ & $-0.902^{* *}$ & $-0.854^{* *}$ \\
\hline
\end{tabular}

Each yearly depth mean was considered an observation $(n=12$; no samples for 1994-97). Correlation analysis performed on $\ln +1$ transformed values.

Significant at ${ }^{*} P<0.05 ;{ }^{* *} P<0.01$.
10-12 years. The native amphipod Diporeia has been replaced by the invasive mussel $D$. r. bugensis as the dominant benthic organism in the lake, and overall benthic biomass has increased. In general, the decline of Diporeia in Lake Michigan is comparable to declines found in Lakes Huron and Ontario over the same general time period (Nalepa et al., 2007; Watkins et al., 2007). At depths of 30-90 m, the Diporeia population declined 96\% between 1994/1995 and 2005 in Lake Michigan, declined 99\% between 1994 and 2003 in Lake Ontario, and declined 93\% between 2000 and 2007 in Lake Huron (Fig. 5). On a broad scale, declines in all three lakes coincided with the introduction and expansion of the dreissenid population; decreased densities of Diporeia are evident even at dreissenid densities of less than $1000 \mathrm{~m}^{-2}$ (Fig. 6).

As mentioned previously, reasons for the negative association between Diporeia and Dreissena are not clear. A common early hypothesis was that Diporeia were being out-competed for available food resources (Dermott \& Kerec, 1997; Nalepa et al., 1998). Dreissenids are filter-feeders that inhabit the sediment surface, whereas Diporeia is a detritivore that feeds in the upper few centimeters of sediment. Dreissenids would thus have access to freshly-settled organic material before Diporeia. Assuming that Diporeia is dependent on pelagic food inputs in offshore waters, it follows that Diporeia could be out-competed for settling food and hence show measurable signs of starvation as the population declined. In Diporeia and other deepwater amphipods, lipid levels are a good

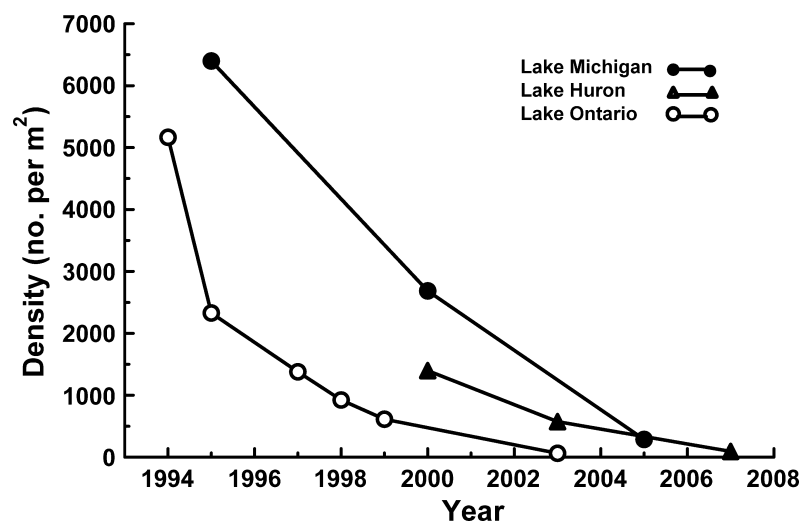

Fig. 5 Trends in mean density (no. $\mathrm{m}^{-2}$ ) of Diporeia in Lake Michigan (this study), Lake Ontario (Watkins et al., 2007), and Lake Huron (Nalepa et al., 2007; T.F. Nalepa, unpubl. data) at a depth of 30-90 m between 1994 and 2007. Solid circle, Lake Michigan; open circle, Lake Ontario; solid triangle, Lake Huron. 


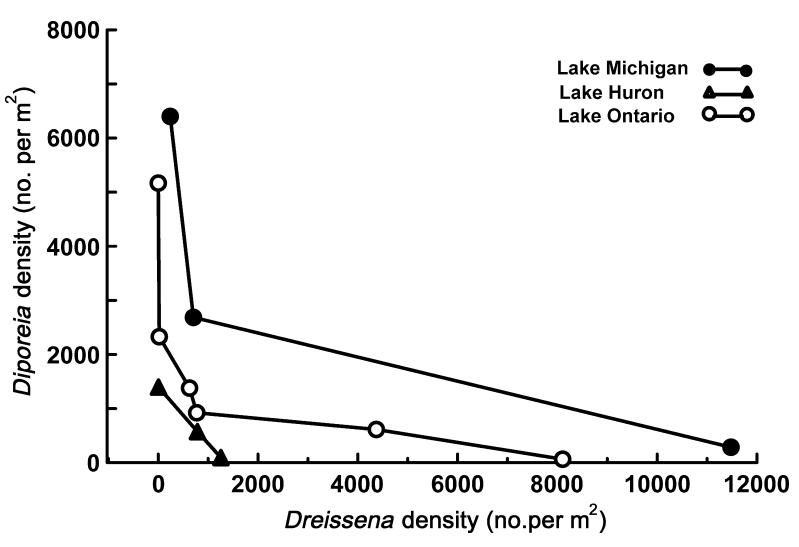

Fig. 6 Relationship between mean densities (no. $\mathrm{m}^{-2}$ ) of Diporeia and Dreissena in Lake Michigan (this study), Lake Ontario (Watkins et al., 2007) and Lake Huron (Nalepa et al., 2007; T.F. Nalepa unpubl. data) at a depth of 30-90 m between 1994 and 2007. Solid circle, Lake Michigan; open circle, Lake Ontario; solid triangle, Lake Huron.

indicator of available food, increasing in the spring when benthic food inputs are high, and then decreasing later when food inputs are minimal (Gardner et al., 1985; Hill et al., 1992; Lehtonen, 1996). By utilizing lipid stores, Diporeia can be highly resistant to food deprivation. In laboratory experiments, Diporeia survived for up to 120 days with little or no food as lipid levels declined from $30 \%$ to $12 \%$ (Gauvin, Gardner \& Quigley, 1989). Inconsistent with the food-limitation hypothesis, lipid levels and weight per unit length did not decrease as the population declined at several Lake Michigan sites (Nalepa et al., 2006a). Further, sedimentation traps indicated at least some organic material (including diatoms as indicated by silica flux) was still settling to the bottom in areas where Diporeia had disappeared and dreissenids were not present (Nalepa et al., 2006a). Similar declines have been recorded in areas removed from dreissenid populations and with seemingly adequate food resources in the water column (diatoms) (Dermott, 2001; Nalepa et al., 2003). Given this, it would be paradoxical to assume that food-deprivation would be the only cause for the population decline. In this study, there was a strong negative correlation between Dreissena densities at shallow sites and Diporeia densities at deep sites, and this is consistent with the finding that the progressive decline of Diporeia from shallow to deeper waters generally precedes the shallow-to-deep expansion of dreissenids (Nalepa et al., 2007; Watkins et al., 2007). The remote influence of dreissenids on Diporeia suggests that some unknown agent associated with dreissenids is being transported beyond areas colonized by these mussels. Diporeia survival was reduced by $25 \%$ when exposed to dreissenid pseudofaeces for 90 days in laboratory experiments, giving credence to the alternative hypothesis that an agent associated with dreissenid biodeposits is having a negative influence (Dermott et al., 2005). Since dreissenid biodeposits are loosely aggregated and therefore readily re-suspended (Hecky et al., 2004), this material may be transported beyond mussels beds and remotely affect Diporeia. Of course, inconsistent with this hypothesis is the coexistence of Diporeia and dreissenids in some locations for extended periods. In this study, Diporeia and dreissenids coexisted for 14 years at a $20 \mathrm{~m}$ site in the southern basin before the former taxa disappeared in 2007.

In general, deep-water amphipods appear to be highly sensitive to environmental perturbations. In European waters, there are records of rapid and extended declines in populations of the closely-related amphipod Monoporeia affinis Lindström. Over a 40year period, Goedkoop (2006) documented annual density fluctuations between fewer than $10 \mathrm{~m}^{-2}$ and $10000 \mathrm{~m}^{-2}$ in M. affinis at sites deeper than $30 \mathrm{~m}$ in Swedish lakes. In some lakes, low densities could be related to periodic low oxygen concentrations in the profundal zone, but in other lakes, low annual densities could not be clearly attributed to any environmental stress. In the Baltic Sea, M. affinis has a natural population cycle of 6-7 years, with densities periodically declining to near zero only to increase within a few years (Sarvala, 1986). However, recent broad declines of M. affinis in the Baltic Sea appear to be unrelated to intrinsic factors (Cederwall, Jermakovs \& Lagzdins, 1999; Kotta \& Olafsson, 2003) and may reflect a disruption in benthic food inputs because of compositional shifts in phytoplankton. That is, the phytoplankton community has shifted from diatoms to dinoflagellates and, because the latter do not settle to the bottom as readily as the former, less food would be available to M. affinis (A.K.E. Wiklund, B. Sundelin \& R. Rosa, unpublished data). Although Diporeia were generally not present in local areas subject to environmental degradation in the Great Lakes in the 1970s (Nalepa \& Thomas, 1976; Vander Wal, 1977; Kraft, 1979), the recent, broad disappearance of this organism in Lake Michigan and 
474 T. F. Nalepa et al.

the other Great Lakes is unique to this system and unlike declines of M. affinis observed in European waters. For one thing, monitoring of Diporeia in offshore waters of Lake Michigan indicated that the population was generally stable from year-to-year in the pre-Driessena period (in 1980s; see Fig. 2). Moreover, there has been no indication of a recovery in Lake Michigan or in any of the other Great Lakes once the population has disappeared from a given area.

Prior to its decline, Diporeia dominated and thrived in the offshore region of Lake Michigan because it was well-adapted to seasonal variations in benthic food inputs. Most organic material settling to the bottom occurred during the diatom bloom in the spring when cold temperatures hinder decomposition during settlement through the water column, and zooplankton grazers are at a minimum (Scavia \& Fahnenstiel, 1987). As noted, Diporeia fed intensively during this period and accumulated lipids that reached as high as $50 \%$ of its DW by late spring (Gardner et al., 1990). After stratification, benthic food inputs were minimal, and Diporeia relied on stored lipids to survive and reproduce. In contrast, lipid levels of D. r. bugensis in Lake Michigan are consistently below 20\% and levels of glycogen, another pathway of energy storage in mussels, are less than $4 \%$ of dry body weight (T.F. Nalepa, unpubl. data). How then can D. r. bugensis thrive in an environment characterized by low, intermittent food inputs and continuously cold temperatures? Insights into the suitability of D. r. bugensis for this harsh environment can be derived from several studies that compared physiological traits of D. r. bugensis and D. polymorpha to determine why the former species was displacing the latter in the Great Lakes. In one study, D. r. bugensis was found to have a higher assimilation efficiency than D. polymorpha, especially at lower food levels ( $81 \%$ versus $63 \%$; Baldwin et al., 2002). Thus, it is able to maintain higher growth and fecundity rates with less available food. In the other study, D. r. bugensis had a lower respiration rate under a wide range of temperature regimes compared to D. polymorpha (Stoeckmann, 2003). Lower respiration rates decrease metabolic costs and further increase the efficient utilization of assimilated material. At low levels of natural seston (i.e. $1 \mu \mathrm{g} \mathrm{L}^{-1} \mathrm{Chl}$ ), D. r. bugensis grew 19 times faster than D. polymorpha (Baldwin et al., 2002). These low levels are now generally found in offshore waters of Lake Michigan (Lesht \& Wortman, 2007). Moreover,
D. r. bugensis allocates more energy to soft tissue relative to shell compared to $D$. polymorpha, giving it a further advantage (Roe \& MacIsaac, 1997).

Conceivably then, because of a relatively high assimilation efficiency and a low respiration rate, D. r. bugensis can sustain growth and reproduction at low food levels without relying on energy stores as does Diporeia. It should be noted that assimilation efficiency is a function of food quality, and the experimentally-derived assimilation efficiency of $81 \%$ reported for D. r. bugensis occurred when food quality was high (Baldwin et al., 2002). In comparison, Dermott (1995) found that the maximum assimilation efficiency of Diporeia over a seasonal period was $42 \%$ (as corrected for selective ingestion). This maximum occurred in June just after the spring bloom when food quality was at a peak. This value is comparable to an assimilation efficiency of $40 \%$ for $M$. affinis when feeding on freshly-deposited organic material collected in the spring in the Baltic Sea (Lopez \& Elmgren, 1989). Thus, when food quality is high, assimilation efficiency of D. $r$. bugensis appears to be twice that of Diporeia.

Another key physiological trait when considering adaptation to low food environments is growth efficiency, or the proportion of assimilated material that is incorporated into production relative to that respired. In offshore waters, growth efficiency for Diporeia was 33-35\% (Johnson \& Brinkhurst, 1971; Fitzgerald \& Gardner, 1993). The growth efficiency of $D$. r. bugensis in offshore regions is unknown, but some indication of relative growth efficiencies of these two taxa can be derived by comparing respiration rates. Johannsson et al. (1985) determined respiration rates of Diporeia at several sites below the thermocline in Lake Ontario and provided a regression equation relating rates to water temperature. From their equation, the respiration rate of Diporeia at $4{ }^{\circ} \mathrm{C}$ was determined to be $1.29 \mu \mathrm{g} \mathrm{O}_{2} \mathrm{mg} \mathrm{DW} \mathrm{h}^{-1}$. In comparison, the respiration rate of D. r. bugensis at $4{ }^{\circ} \mathrm{C}$ was determined to be about $0.87 \mu \mathrm{g} \mathrm{O}_{2} \mathrm{mg} \mathrm{DW} \mathrm{h}^{-1}$ (Stoeckmann, 2003), or about $33 \%$ lower than Diporeia. This is not unexpected since a stationary filter-feeder like $D$. $r$. bugensis would be less active than a burrowing detritivore like Diporeia. As noted earlier, lower respiration rates would allow more assimilated energy to be utilized for growth and reproduction.

The replacement of Diporeia by D. r. bugensis can be viewed as a process that has caused a major disruption 
in the energy flow through the benthic community. That is, energy once efficiently cycled through Diporeia to upper trophic levels now resides in dreissenid biomass or is lost to the system, and the benthic community now serves as a major energy sink rather than a pathway. As found in this study, mean lakewide biomass of D. r. bugensis was $28.6 \mathrm{~g} \mathrm{DW} \mathrm{m}^{-2}$ in 2005. When the proportion of depth-specific biomass in the southern basin relative to the entire lake was calculated for 2005 and proportionately applied to the entire lake based on the 2007 data, the mean lake-wide biomass in 2007 was estimated to be $80 \mathrm{~g} \mathrm{DW} \mathrm{m}^{-2}$. Assuming Diporeia has an energy content of $1159 \mathrm{cal} \mathrm{g}^{-1}$ wet weight (WW) (McNickle, Rennie \& Sprules, 2006), the biomass of $3.9 \mathrm{~g} \mathrm{DW} \mathrm{m}^{-2}$ found in $1994 / 1995$ was equivalent to $14.5 \mathrm{~g} \mathrm{WW} \mathrm{m}^{-2}$ (DW $=27 \% W W$; Landrum, 1988) and represented an energy pool of $16.8 \mathrm{kcal} \mathrm{m}^{-2}$. Assuming Dreissena has an energy content of $580 \mathrm{cal} \mathrm{g}^{-1}$ WW (Schneider, 1992), the $28.6 \mathrm{~g} \mathrm{DW} \mathrm{m}^{-2}$ biomass of D. r. bugensis in 2005 was equivalent to $188 \mathrm{~g} \mathrm{WW} \mathrm{m}^{-2}$ (DW $=15 \%$ WW, Schneider, 1992) and represented an energy pool of $109 \mathrm{kcal} \mathrm{m}^{-2}$. Ignoring the low biomass of dreissenids in 1994/95 and the low biomass of Diporeia in 2005 and assuming biomass contribution of other taxa is minimal (Nalepa, 1989; Nalepa et al., 1998), this represents a 6.5 -fold increase in the lake-wide benthic energy pool in 10 years. When estimated for 2007, this energy pool was $342 \mathrm{kcal} \mathrm{m}^{-2}$, a 20-fold increase over 1994/1995.

In addition to having a relatively low respiration rate and a high assimilation efficiency compared to Diporeia, the high energy pool achieved by D. $r$. bugensis can be partly explained by its feeding mode. An active filter-feeder like D. r. bugensis has access to pelagic production during the entire unstratified period, while a passive detritivore like Diporeia has access to such production mostly in the spring when conditions favour pelagic deposition.

Of course, the concept of an energy sink is only valid if D. r. bugensis is not being fed upon by upper trophic levels, and this is not entirely true. For example, large lake whitefish (Coregonis clupeaformis [Mitchill]) are now feeding almost exclusively on D. $r$. bugensis, when previously these fish fed mostly on Diporeia (Pothoven \& Nalepa, 2006). The problem with switching from Diporeia to D. r. bugensis lies in the ingestion of the dreissenid shell, which comprises more than $80 \%$ of total dry mass in D. r. bugensis (Roe
\& MacIsaac, 1997). The shell offers little nutritional value, but represents an energetic cost to the fish in terms of handling and digestion. Further, the amount of energy placed into shell growth by dreissenids is unknown, but in marine mussels it is $50 \%$ of production (Kuenzler, 1961). In the constantly cold waters of offshore regions, production in all taxa is about equal to biomass (i.e. $\mathrm{P} / \mathrm{B}=1$; Johnson \& Brinkhurst, 1971). Therefore, the energy sink represented by $D$. $r$. bugensis can be $50 \%$ greater than represented by standing biomass if the cost of producing the shell is also considered. Energy is lost to the food web when the shell is ingested, and also lost when the shell is produced.

Recent studies suggest that the disappearance of Diporeia, an energy-rich, readily-available food source, is having a negative impact on fish communities in Lake Michigan and other Great Lakes (i.e. Lakes Huron and Ontario) (Mohr \& Nalepa, 2005). For example, the diet, abundance and energy density of alewife (Alosa pseudoharengus [Wilson]), sculpin (Cottus cognatus Richardson and Myoxocephalus thompsonii [Girard]), and bloater (Coregonus hoyi [Gill]), were examined in areas of southeastern Lake Michigan with and without Diporeia (Hondorp, Pothoven \& Brandt, 2005). These fish species serve as important prey of the larger piscivores within the lake. In the area with no Diporeia, fish feeding habits were altered, and abundance and energy density were significantly lower than fish from the area where Diporeia was still present. Further, energy density of alewife in the lake has declined $23 \%$, and condition of lake whitefish has decreased 27\% since the mid-1990s when Diporeia began declining (Pothoven et al., 2001; Madenjian et al., 2006). More recently, total biomass (WW) of prey fish in Lake Michigan has declined from 91 kilotonnes in 2005 to 31 kilotonnes in 2007, which is down from 450 kilotonnes in 1989 (C. Madenjian, pers. comm.). Based on our study, total WW biomass (shell and soft tissue) of D. r. bugensis was 36 kilotonnes in 2005 and estimated to have increased to 113 kilotonnes in 2007 (assuming tissue DW is 5\% total WW in D. r. bugensis, T.F. Nalepa, unpubl. data). Other factors besides a decline in Diporeia and an increase in dreissenid biomass may have contributed to the loss of prey fish biomass (Bunnell et al., 2009), but, nevertheless, total dreissenid biomass (tissue and shell) is now estimated to be about 3.8 times greater than prey fish biomass within the lake. 
Presently in Lake Michigan, Diporeia have disappeared to depths of $90 \mathrm{~m}$, and current trends indicate that populations at depths greater than $90 \mathrm{~m}$ are now in a state of decline. Exact reasons for the disappearance of Diporeia are not entirely clear but, based on past trends, the expected increase of D. r. bugensis at depths greater than $90 \mathrm{~m}$ portends a continued loss of Diporeia within this deep region. During the initial stages of expansion, most dreissenid populations tend to follow a boom-and-bust scenario, with populations increasing rapidly for a period followed by a decline to more stable, sustainable levels (Strayer \& Malcom, 2006). In 2007, the D. r. bugensis population in Lake Michigan was still expanding, and we estimate that lake-wide biomass was at least three times greater than found in 2005. Yet even though the population will stabilize and decline at some point, it is unlikely that Diporeia will soon recover since extirpation occurs even at low densities of Dreissena. As shown, the disappearance of Diporeia has progressed from shallow to deep water over time, and its recent rapid decline at 51-90 m coincides with the increase of D. $r$. bugensis at this depth interval. Given evidence that fish prefer to feed on Diporeia even when densities are low (Hondorp et al., 2005) and most prey fish are found at depths less than $90 \mathrm{~m}$ (Wells, 1980), the recent decline of Diporeia at depths of 51-90 m would indicate that further impacts on the fish community are forthcoming.

\section{Acknowledgments}

We thank the crews of the $R / V$ Shenehon, $R / V$ Laurentian and $\mathrm{R} / \mathrm{V}$ Lake Guardian for their support during field operations; the Great Lakes National Program Office, U. S. EPA for use of the Lake Guardian; the many excellent assistants that helped to collect samples and count organisms during the many years of this study; Steve Lozano for his early support and Tomas Hook and Michael Quigley for their insightful comments on the manuscript. This is GLERL Publication Number 1480.

\section{References}

Baldwin B.S., Mayer M.S., Dayton J., Pau N., Mendilla J., Sullivan M., Moore A., Ma A. \& Mills E.L. (2002) Comparative growth and feeding in zebra and guagga mussels (Dreissena polymorpha and Dreissena bugensis): implications for North American lakes. Canadian Journal of Fisheries and Aquatic Sciences, 59, 680-694.

Bousfield E.L. (1989) Revised morphological relationships within the amphipod genera Pontoporeia and Gammaracanthus and the "glacial relict" significance of their postglacial distributions. Canadian Journal of Fisheries and Aquatic Sciences, 46, 1714-1725.

Bunnell D.B., Madenjian C.P., Holuszko J.D., Desorcie T.J., Adams J.V. \& French J.R.P. III (2009) Expansion of Dreissena into offshore waters of Lake Michigan, 20042007, and potential impacts on fish. Journal of Great Lakes Research. (In press).

Cederwall H., Jermakovs V. \& Lagzdins G. (1999) Longterm changes in the soft-bottom macrofauna of the Gulf of Riga. ICES Journal of Marine Science, 56(Suppl.), 41-48.

Cook D.G. \& Johnson M.G. (1974) Benthic macroinvertebrates of the St. Lawrence Great Lakes. Journal of Fisheries Research Board of Canada, 31, 763-782.

Covich A.P., Palmer M.A. \& Crowl T.A. (1999) The role of benthic invertebrate species in freshwater ecosystems. BioScience, 49, 119-127.

Crooks J.A. \& Soule M.E. (1999) Lag times in population explosions of invasive species: causes and implications. In: Invasive Species and Biodiversity Management (Eds O.T. Sandlund, P.J. Schei \& A. Viken), pp. 103125. Kluwer Academic Publishers, Dordrecht, The Netherlands.

Dermott R. (1995) Production and Growth Efficiency of two Burrowing Invertebrates, Hexagenia limbata and Diporeia hoyi, in Batchawana Bay, Lake Superior. Canadian Technical Report for Fisheries and Aquatic Sciences, 2034, Fisheries and Oceans Canada, Burlington, ON, $28 \mathrm{p}$.

Dermott R. (2001) Sudden disappearance of the amphipod Diporeia from eastern Lake Ontario, 1993-1995. Journal of Great Lakes Research, 27, 423-433.

Dermott R. \& Corning K. (1988) Seasonal ingestion rates of Pontoporeia hoyi (Amphipoda) in Lake Ontario. Canadian Journal of Fisheries and Aquatic Sciences, 45, 1886-1895.

Dermott R. \& Kerec D. (1997) Changes in the deepwater benthos of eastern Lake Erie since the invasion of Dreissena: 1979-1993. Canadian Journal of Fisheries and Aquatic Sciences, 54, 922-930.

Dermott R. \& Munawar M. (1993) Invasion of Lake erie offshore sediments by Dreissena, and its ecological implications. Canadian Journal of Fisheries and Aquatic Sciences, 50, 2298-2304.

Dermott R., Munawar M., Bonnell R., Carou S., Niblock H., Nalepa T.F. \& Messick G.A. (2005) Preliminary investigations into causes of the disappearance of Diporeia from Lake Ontario. In: Proceedings of a 
Workshop on the Dynamics of the Lake Whitefish (Coregonus clupeaformis) and the Amphipod Diporeia spp. in the Great Lakes (Eds L.C. Mohr \& T.F. Nalepa), pp. 203-232. Great Lakes Fishery Commission Technical Report 69, Great Lakes Fishery Commission, Ann Arbor, MI.

Diamond J. \& Case T.J. (1986) Overview: introductions, extinctions, exterminations, and invasions. In: Community Ecology (Eds J. Diamond \& T.J. Case), pp.65-79. Harper and Rowe, New York.

Dick J.T.A. \& Platvoet D. (2000) Invading predatory crustacean Dikerogammarus villosus eliminated both native and exotic species. Proceedings of the Royal Academy of London, B, 267, 977-983.

Fitzgerald S.A. \& Gardner W.S. (1993) An algal carbon budget for pelagic-benthic coupling in Lake Michigan. Limnology and Oceanography, 38, 547-560.

Gardner W.S., Nalepa T.F., Frez W.A., Cichocki E.A. \& Landrum P.F. (1985) Seasonal patterns in lipid content of Lake Michigan macroinvertebrates. Canadian Journal of Fisheries and Aquatic Sciences, 42, 1827-1832.

Gardner W.S., Eadie B.J., Chandler J.F., Parrish C.C. \& Malczyk J.M. (1989) Mass flux and "nutritional composition" of settling eplimnetic particles in Lake Michigan. Canadian Journal of Fisheries and Aquatic Sciences, 46, 1118-1124.

Gardner W.S., Quigley M.A., Fahnenstiel G.L., Scavia D. \& Frez W.A. (1990) Pontoporeia hoyi - a direct trophic link between spring diatoms and fish in Lake Michigan. In: Large Lakes: Ecological Structure and Function (Eds M.M. Tilzer \& C. Serruya), pp. 632-644. Springer, New York.

Gauvin J.M., Gardner W.S. \& Quigley M.A. (1989) Effects of food removal on nutrient release rates and lipid content of Lake Michigan Pontoporeia hoyi. Canadian Journal of Fisheries and Aquatic Sciences, 46, 1125-1130.

Goedkoop W. (2006) Multiple stressors acting on populations of the glacial relict amphipod Monoporeia affinis (Lindstrom) in Lake Malaren, Sweden. Verhandlugan Internationale Verein Limnologia, 29, 1789-1795.

Green R.H. (1993) Application of repeated-measures designs in environmental impact and monitoring studies. Australian Journal of Ecology, 18, 81-98.

Guiguer K.R.R.A. \& Barton D.R. (2002) The trophic role of Diporeia (Amphipoda) in Colpys Bay (Georgian Bay) benthic food web: a stable isotope approach. Journal of Great Lakes Research, 28, 228-239.

Hecky R.E., Smith R.E.H., Barton D.R., Guildford S.J., Taylor W.D., Charlton M.N. \& Howell T. (2004) The nearshore phosphorus shunt: a consequence of ecosystem engineering by dreissenids in the Laurentian Great Lakes. Canadian Journal of Fisheries and Aquatic Science, 61, 1285-1293.
Hill C., Quigley M.A., Cavaletto J.F. \& Gordon W. (1992) Seasonal changes in lipid content and composition in the benthic amphipods Monoporeia affinis and Pontoporeia femorata. Limnology and Oceanography, 37, 1280-1289.

Hondorp D.W., Pothoven S.A. \& Brandt S.B. (2005) Influence of Diporeia density on the diet composition, relative abundance, and energy density of planktivorous fishes in southeast Lake Michigan. Transactions of the American fisheries Society, 134, 588-601.

Johannsson O.E., Dermott R.M., Feldkamp R. \& Moore J.E. (1985) Lake Ontario Long Term Monitoring Program. Report for 1981 and 1982. Canadian Technical Report for Fisheries and Aquatic Sciences No. 1414, Fisheries and Oceans Canada, Burlington, ON.

Johnson M.G. \& Brinkhurst R.O. (1971) Production of benthic macroinvertebrates of Bay of Quinte and Lake Ontario. Journal of Fisheries Research Board of Canada, 28, 1699-1714.

Kotta J. \& Olafsson E. (2003) Competition for food between the introduced polychaete Marenzelleria viridis (Verrill) and the native amphipod Monoporeia affinis Lindstrom in the Baltic Sea. Journal of Sea Research, 50, 27-35.

Kraft K.J. (1979) Pontoporeia distributions along the Keweenaw shore of Lake Superior affected by copper tailings. Journal of Great Lakes Research, 5, 28-35.

Kuenzler E.J. (1961) Structure and energy flow of a mussel population in a Georgia salt marsh. Limnology and Oceanography, 6, 191-204.

Landrum P.F. (1988) Toxicokinetics of organic xenobiotics in the amphipod, Pontoporeia hoyi: role of physiological and environmental variables. Aquatic Toxicology, 12, 245-271.

Lehtonen K.K. (1996) Ecophysiology of the benthic amphipod Monoporeia affinis in an open-sea area of the northern Baltic Sea: seasonal variations in body composition, with bioenergetic considerations. Marine Ecology Progress Series, 143, 87-98.

Lesht B.M. \& Wortman S.R. (2007) Long Time Series of Satellite Observations: Analysis and Interpretation. Abstract, 50th Annual Conference on Great Lakes Research, International Association for Great Lakes Research, Ann Arbor, MI.

Lodge D.M. (1993) Biological invasions: lessons for ecology. Trends in Evolution and Ecology, 8, 133-136.

Lopez G. \& Elmgren R. (1989) Feeding depths and organic absorption for the deposit-feeding benthic amphipods Pontoporeia affinis and Pontoporeia femorata. Limnology and Oceanography, 34, 982-991.

Madenjian C.P., Pothoven S.A., Dettmers J.M. \& Holuszko J.D. (2006) Changes in seasonal energy dynamics of alewife (Alosa pseudoharengus) in Lake Michigan after invasion of dreissenid mussels. Canadian Journal of Fisheries and Aquatic Sciences, 63, 891-902. 
McNickle G.G., Rennie M.D. \& Sprules W.G. (2006) Changes in benthic invertebrate communities of South Bay, Lake Huron following invasion by zebra mussels (Dreissena polymorpha), and potential effects on Lake Whitefish (Coregonus clupeaformis) diet and growth. Journal of Great Lakes Research, 32, 180-193.

Mills E.L., Chrisman J.R., Baldwin B., Owens R.W., O'Gorman R., Howell T., Roseman E.F. \& Raths M.K. (1999) Changes in the dreissenid community in the lower Great Lakes with emphasis on southern Lake Ontario. Journal of Great Lakes Research, 25, 187-197.

Mohr L.C. \& Nalepa T.F. (2005) Proceedings of a Workshop on the Dynamics of the Lake Whitefish (Coregonus clupeaformis) and the Amphipod Diporeia spp. in the Great Lakes. Great Lakes Fishery Commission Technical Report 69, Great Lakes Fishery Commission, Ann Arbor, MI.

Moyle P.B. \& Light T. (1996) Biological invasions of fresh water: empirical rules and assembly theory. Biological Conservation, 78, 149-161.

Nalepa T.F. (1989) Estimates of macroinvertebrate biomass in Lake Michigan. Journal of Great Lakes Research, 15, 437-443.

Nalepa T.F. \& Thomas N.A. (1976) Distribution of macrobenthic species in Lake Ontario in relation to sources of pollution and sediment parameters. Journal of Great Lakes Research, 2, 150-163.

Nalepa T.F., Hartson D.J., Fanslow D.L., Lang G.A. \& Lozano S.J. (1998) Declines in benthic macroinvertebrate populations in southern Lake Michigan, 19801993. Canadian Journal of Fisheries and Aquatic Sciences, 55, 2402-2413.

Nalepa T.F., Hartson D.J., Buchanan J., Cavaletto J.F., Lang G.A. \& Lozano S.J. (2000) Spatial variation in density, mean size and physiological condition of the holarctic amphipod Diporeia spp. in Lake Michigan. Freshwater Biology, 43, 107-119.

Nalepa T.F., Schloesser D.W., Pothoven S.A., Hondorp D.W., Fanslow D.L., Tuchman M.L. \& Fleischer G.W. (2001) First finding of the amphipod Echinogammarus ischnus and the mussel Dreissena bugensis in Lake Michigan. Journal of Great Lakes Research, 27, 384-391.

Nalepa T.F., Fanslow D.L., Lansing M.B. \& Lang G.A. (2003) Trends in the benthic macroinvertebrate community of Saginaw Bay, Lake Huron, 1987 to 1996: responses to phosphorus abatement and the zebra mussel, Dreissena polymorpha. Journal of Great Lakes Research, 29, 14-33.

Nalepa T.F., Fanslow D.L., Foley A.J. III, Lang G.A., Eadie B.J. \& Quigley M.A. (2006a) Continued disappearance of the benthic amphipod Diporeia spp. in Lake Michigan: is there evidence for food limitation? Canadian Journal of Fisheries and Aquatic Sciences, 63, 872-890.
Nalepa T.F., Rockwell D.C. \& Schloesser D.W. (2006b) Disappearance of the Amphipod Diporeia spp. in the Great Lakes: Workshop Summary, Discussion, and Recommendations. NOAA Technical Memorandum GLERL-136. NOAA, Great Lakes Environmental Research Laboratory, Ann Arbor, MI.

Nalepa T.F., Fanslow D.L., Pothoven S.A., Foley A.J. III \& Lang G.A. (2007) Long-term trends in benthic macroinvertebrate populations in Lake Huron over the past four decades. Journal of Great Lakes Research, 33, 421-436.

Nalepa T.F., Fanslow D.L., Lang G.A., Lamarand D.B., Cummins L.G. \& Carter G.S. (2008) Abundances of the Amphipod Diporeia spp. and the Mussels Dreissena polymorpha and Dreissena rostriformis bugensis in Lake Michigan in 1994-1995, 2000, and 2005. NOAA Technical Memorandum GLERL-144. NOAA Great Lakes Environmental Research Laboratory, Ann Arbor, MI.

Palmer M.E. \& Ricciardi A. (2005) Community interactions affecting the relative abundances of native and invasive amphipods in the St. Lawrence River. Canadian Journal of Fisheries and Aquatic Sciences, 62, 1111-1118.

Pothoven S.A. \& Nalepa T.F. (2006) Feeding ecology of lake whitefish in Lake Huron. Journal of Great Lakes Research, 32, 489-501.

Pothoven S.A., Nalepa T.F., Schneeberger P.J. \& Brandt S.B. (2001) Changes in diet and body condition of lake whitefish in southern Lake Michigan associated with changes in benthos. North American Journal of Fisheries Management, 21, 876-883.

Richter B.D., Braun D.P., Mendelson M.A. \& Master L.L. (1997) Threats to imperiled freshwater fauna. Conservation Biology, 11, 1081-1093.

Roe S.L. \& MacIsaac H.J. (1997) Deepwater population structure and reproductive state of quagga mussels (Dreissena bugensis) in Lake Erie. Canadian Journal of Fisheries and Aquatic Sciences, 54, 2428-2433.

Sarvala J. (1986) Interannual variation of growth and recruitment in Pontoporeia affinis (Lindstrom) (Crustacea: Amphipoda) in relation to abundance fluctuations. Journal of Experimental Marine Biology and Ecology, 101, 41-59.

Scavia D. \& Fahnenstiel G.L. (1987) Dynamics of Lake Michigan phytoplankton: mechanisms controlling epilimnetic communities. Journal of Great Lakes Research, 13, 103-120.

Schneider D.W. (1992) A bioenergetics model of zebra mussel, Dreissena polymorpha, growth in the Great Lakes. Canadian Journal of Fisheries and Aquatic Sciences, 49, 1406-1416.

Scott W.B. \& Crossman E.J. (1973) Freshwater Fishes of Canada. Bulletin of the Fisheries Research Board of Canada 184, Department of the Environment, Ottawa, ON. 
Sierszen M.A., Peterson G.S. \& Scharold J.V. (2006) Depth-specific patterns in benthic-planktonic food web relationships in Lake Superior. Canadian Journal of Fisheries and Aquatic Sciences, 63, 1496-1503.

Simon K.S. \& Townsend C.R. (2003) Impacts of freshwater invaders at different levels of organization, with emphasis on salmonids and ecological consequences. Freshwater Biology, 48, 982-994.

Stoeckmann A. (2003) Physiological energetics of Lake Erie dreissenid mussels: a basis for the displacement of Dreissena polymorpha by Dreissena bugensis. Canadian Journal of Fisheries and Aquatic Sciences, 60, 126-134.

Strayer D.L. \& Malcom H.M. (2006) Long-term demography of a zebra mussel (Dreissena polymorpha) population. Freshwater Biology, 51, 117-130.
Vander Wal J. (1977) Relations between Nipigon Bay macroinvertebrates and selected aspects of their habitat. Journal of the Fisheries Research Board of Canada, 34, 824-829.

Watkins J.M., Dermott R., Lozano S.J., Mills E.L., Rudstram L.G. \& Scharold J.V. (2007) Evidence for remote effects of dreissenid mussels on the amphipod Diporeia: analysis of Lake Ontario benthic surveys, 1972-2003. Journal of Great Lakes Research, 33, 642-657.

Wells L. (1980) Food of Alewives, Yellow Perch, Spottail Shiners, Trout-Perch, and Slimy and Fourhorn Sculpins in Southeastern Lake Michigan. United States Fish and Wildlife Service Technical Report 98, Ann Arbor, MI.

(Manuscript accepted 10 September 2008) 